\title{
Mitochondrial DNA alterations correlate with the pathological status and the immunological ER, PR, HER-2/neu, p53 and Ki-67 expression in breast invasive ductal carcinoma
}

\author{
CHEN-SUNG LIN ${ }^{1,2,6^{*}}$, SHI-CHUAN CHANG ${ }^{3,10^{*}}$, LIANG-HUNG OU ${ }^{2,7}$, CHIEN-MING CHEN $^{8}$, \\ SOPHIE SWEN-WAN HSIEH ${ }^{9}$, YU-PING CHUNG ${ }^{9}$, KUANG-LIANG KING ${ }^{2,11}$, \\ SHOEI-LOONG LIN ${ }^{2,7,12}$ and YAU-HUEI WEI ${ }^{1,2,4,5}$
}

\author{
${ }^{1}$ Institute of Clinical Medicine, ${ }^{2}$ Faculty of Medicine, ${ }^{3}$ Institute of Emergency and Critical Care Medicine, and \\ ${ }^{4}$ Institute of Biochemistry and Molecular Biology, National Yang-Ming University, Taipei 112; ${ }^{5}$ Department of Medicine, \\ Mackay Medical College, New Taipei City 252; ${ }^{6}$ Division of Thoracic Surgery and ${ }^{7}$ Division of General Surgery, \\ Department of Surgery, ${ }^{8}$ Division of Hematology and Oncology, Department of Internal Medicine, and \\ ${ }^{9}$ Department of Pathology, Taipei Hospital, Ministry of Health and Welfare, New Taipei City 242; \\ ${ }^{10}$ Division of General Chest Medicine, Department of Chest, and ${ }^{11}$ Division of General Surgery, \\ Department of Surgery, Taipei Veterans General Hospital, Taipei $112 ;{ }^{12}$ Chon-inn Hospital, \\ Chon-inn Healthcare Corp. Aggregate, New Taipei City 220, Taiwan, R.O.C.
}

Received December 22, 2014; Accepted February 19, 2015

DOI: $10.3892 /$ or.2015.3887

\begin{abstract}
We analyzed the changes in mitochondrial DNA (mtDNA) copy numbers and the shifting of mtDNA D310 sequence variations (D310 mutation) with their relationships to pathological status and the expression levels of estrogen receptor (ER), progesterone receptor (PR), human epidermal growth factor receptor-2 (HER-2/neu), tumor-suppressor protein $\mathrm{p} 53$ and cellular proliferation protein $\mathrm{Ki}-67$ in breast invasive ductal carcinoma (BIDC), respectively. Fifty-one paraffin-embedded BIDCs and their paired non-cancerous breast tissues were dissected for DNA extraction. The mtDNA copy number and mtDNA D310 sequence variations were determined by quantitative real-time polymerase chain reaction (q-PCR) and PCR-based direct sequencing, respectively. The expression levels of ER, PR, HER-2/neu, p53 and Ki-67 were determined by immunohistochemical (IHC) staining. Compared to the paired non-cancerous breast tissues, 24
\end{abstract}

Correspondence to: Professor Shoei-Loong Lin, Chon-inn Hospital, Chon-inn Healthcare Corp. Aggregate, 196 Section 1, Wen-Hua Road, Banqiao, New Taipei City 220, Taiwan, R.O.C.

E-mail:drslin705@gmail.com

Professor Yau-Huei Wei, Department of Medicine, Mackay Medical College, 46 Section 3, Zhong-Zheng Road, San-Zhi, New Taipei City 252, Taiwan, R.O.C.

E-mail: joeman@mmc.edu.tw

*Contributed equally

Key words: breast invasive ductal carcinoma, mitochondrial DNA copy number, D310 mutation, estrogen receptor, HER-2/neu, protein $\mathrm{Ki}-67$, protein $\mathrm{p} 53$, progesterone receptor
(47.1\%) BIDCs had elevated mtDNA copy numbers and 29 (56.9\%) harbored mtDNA D310 mutations. Advanced T-status $(p=0.056)$, negative-ER $(p=0.005)$, negative-PR $(p=0.007)$, positive-p53 $(\mathrm{p}=0.050)$ and higher Ki-67 $(\mathrm{p}=0.004)$ expressions were related to a higher mtDNA copy ratio. In addition, advanced T-status $(\mathrm{p}=0.019)$ and negative-HER-2/neu expression $(\mathrm{p}=0.061)$ were associated with mtDNA D310 mutations. In conclusion, higher mtDNA copy ratio and D310 mutations may be relevant biomarkers correlated with pathological T-status and the expression levels of ER, PR, HER-2/neu, p53 and Ki-67 in BIDCs.

\section{Introduction}

Mitochondria are the intracellular organelles responsible for ATP production to meet the energy demands (1). Generally, there are several hundred to 1,000 mitochondria in a human cell and 2-10 copies of mitochondrial DNA (mtDNA) in a human mitochondrion to compose the mitochondrial network (2). The amount of mtDNA copies in a human cell is highly variable, depending on the cell type and the surrounding pathophysiological conditions, and usually is positively correlated to the energy demands (3). Different from the heterozygotic nature of nuclear DNA (nDNA), the mtDNA is exclusively transmitted through maternal lineage with a single origin and the majority of mtDNA copies in the post-mitotic tissues are assumed identical after birth. This specific feature is termed as homoplasmy (4). Due to the lack of introns, naked DNA exposure without adequate histone protection, impaired DNA repair system and an environment with high reactive oxygen species (ROS) concentration in the inner membrane of mitochondria, human mtDNA is far more susceptible to oxidative damages or mutations than nDNA (5-7). When the damaged or the 
mutated mtDNA variants coexist with the wild-type inborn mtDNA molecules, the homoplasmy is disrupted and shifted to a condition termed as heteroplasmy (8).

Human mtDNA, containing a coding and a non-coding region, is a circular and double-stranded DNA structure 16.6-kb in size. The inner strand is called the light strand (L) and the outer strand is called the heavy strand $(\mathrm{H})$. Based on the L strand, the entire mtDNA has been sequenced completely as the revised Cambridge Reference Sequence (rCRS) (9). The coding region of mtDNA codes for 13 polypeptides that are required for the composition of respiratory chain complexes, and 2 rRNAs plus a set of 22 tRNAs necessary for protein synthesis in the mitochondria. All the other $\sim 90$ polypeptides constituting the respiratory chain complexes are encoded in nDNA. The non-coding region 1.1-kb in size, also called the displacement loop (D-loop), is the regulatory region for specific protein binding to trigger mtDNA replication and transcription $(10,11)$.

Although damages can occur anywhere throughout the entire mtDNA, they are frequently found in the D-loop, particularly in the D310 region (12). Between nucleotide position (np) 303 and np 316 of the D-loop, there is a poly-cytidine (C) tract with a thymidine (T) interrupted at np $310\left(-\mathrm{C}_{303} \mathrm{CCCCC}\right.$ $\mathrm{CT}_{310} \mathrm{CCCCCC}_{316^{-}}=\mathrm{C}_{7} \mathrm{TC}_{6}$ ). The $\mathrm{C}$ number remains constant as 6 after $\mathrm{T}$, however, it is highly variable before $\mathrm{T}$ with a range from 6 to $12\left(\mathrm{C}_{6}, \mathrm{C}_{7}, \mathrm{C}_{8}, \mathrm{C}_{9}, \mathrm{C}_{10}, \mathrm{C}_{11}\right.$ and $\left.\mathrm{C}_{12}\right)$, and $7\left(\mathrm{C}_{7}\right.$, wild-type) being the most common one. These variations with a T shifting over np 310 of the D-loop in mtDNA are termed as D310 polymorphism or D310 sequence variations (9).

Breast invasive ductal carcinoma (BIDC) is the most commonly diagnosed malignancy worldwide among women (13). Due to the multidisciplinary treatment modalities, including surgical resection and combinations of perioperative chemotherapy, radiotherapy, hormone-ablation or targeted therapies, and the advance in the understanding of its underlying molecular pathogenesis, the associated morbidity and mortality associated with BIDC have been reduced gradually during the past decades (14). In order to achieve an optimal therapeutic result, surgical-pathological T-, N- and M-status and the cancer stage, and the immunological expression levels of estrogen receptor (ER), progesterone receptor (PR), human epidermal growth factor receptor-2 (HER-2/neu), protein p53 and protein $\mathrm{Ki}-67$ are routinely assessed in BIDC patients, at present (15-18). However, the roles of mtDNA alterations in BIDC remain speculative. In this retrospective study, we aimed to appraise the associations among mtDNA alterations, including the change in mtDNA copy number and the shifting of mtDNA D310 sequence variations (D310 mutation), the pathological status, and the immunological ER, PR, HER-2/neu, p53 and Ki-67 expression levels in BICDs, respectively.

\section{Materials and methods}

Patient selection, tissue preparation and DNA extraction. A total of 51 women diagnosed with BIDC, without obvious distant organ metastasis on preoperative assessments, who underwent curative modified radical mastectomy plus axillary lymph node dissection as the primary treatment modality between January 2009 and June 2011 were enrolled. None of the patients received preoperative neoadjuvant chemotherapy, radiotherapy or both. Their pathologic status (TNM and cancer stage according to the American Joint Committee on Cancer; AJCC, 7th edition) and ER, PR, HER-2/neu, p53 and Ki-67 expression levels, and clinical data were recorded in detail for systemic analysis. Approval from the Institutional Review Board was obtained to conduct the present study.

As reviewed by an experienced pathologist, representative areas harboring BIDC and paired non-cancerous breast tissue on pathologic slides were located, and thin sections $(\sim 5-\mu \mathrm{m})$ from matched formalin-fixed and paraffin-embedded tissue blocks were prepared for DNA extraction. These tissue samples were stored in 1.5-ml Eppendorf vials and mixed with $500 \mu 1$ xylene (Merck KGaA, Darmstadt, Germany) at room temperature for $16 \mathrm{~h}$. After centrifuging at $10,000 \mathrm{x} \mathrm{g}$ for $10 \mathrm{~min}$ at room temperature and discarding the supernatants, these tissue samples were re-hydrated with 100, 80, 60 and $40 \%$ alcohol aqueous solution and then pure distilled water for $5 \mathrm{~min}$ in steps. Finally, the hydrated tissue samples were mixed with $200 \mu$ l QuickExtract DNA extraction solution (Epicenter, Madison, WI, USA) plus $3 \mu \mathrm{l}$ of $5 \%$ butylated hydroxytoluene in methanol to extract total cellular DNA at $65^{\circ} \mathrm{C}$ for $3 \mathrm{~h}$ as previously described $(19,20)$. The DNA sample was kept at $-20^{\circ} \mathrm{C}$ until use.

Standard curves for mtDNA and nDNA quantifications. Quantitative real-time polymerase chain reaction (q-PCR) using LightCycler ${ }^{\circledR}$ FastStart DNA Master SYBR-Green I (Roche Applied Science, Mannheim, Germany) to detect threshold cycle $(\mathrm{Ct})$ was applied for mtDNA and nDNA standard curve establishment and subsequent quantification. Briefly, genomic DNA of 143B osteosarcoma cells were 4-fold diluted from 20 to $0.0048828 \mathrm{ng} / \mu \mathrm{l}$ and then subjected to q-PCR for $\mathrm{Ct}$ value determination. The sequences of the primers used for mtDNA amplification (near the ND1 region, mainly coding for tRNA leucine 1) were: $\mathrm{mtF} 3212,5^{\prime}-\mathrm{CACCC}$ AAGAACAGGGTTTGT-3'; and mtR3319,5'-TGGCCATGGG ATTGTTGTTAA-3'. The sequences of primers used for nDNA amplification (18S rRNA region) were: 18SF1546, 5'-T AGAGGGACAAGTGGCGTTC-3'; and 18SR1650, 5'-CGCT GAGCCAGTCAGTGT-3' (21). The equations of standard curves set for mtDNA and nDNA quantification were set as previously described $(19,20,22)$. Then the mtDNA and nDNA copies of the clinical samples relative to mtDNA and nDNA copies of the 143B osteosarcoma cells were calculated.

Determination of mtDNA copy number and mtDNA copy ratio. The mtDNA copy number was defined as the total mtDNA copies divided by the total nDNA copies for each clinical sample. q-PCR was applied for sample mtDNA and nDNA quantification. For each reaction, $1 \mu \mathrm{l}(10 \mathrm{ng} / \mu \mathrm{l})$ of sample DNA was amplified in a $10 \mu \mathrm{l}$ mixture that containing $0.25 \mu \mathrm{l}$ of each primer $(20 \mu \mathrm{M}, \mathrm{mtF} 3212$ and $\mathrm{mtR} 3319$ for mtDNA quantification; 18SF1546 and 18SR1650 for nDNA quantification), $1.2 \mu \mathrm{l}$ of $3 \mathrm{mM} \mathrm{MgCl}_{2}, 1 \mu \mathrm{l}$ of LightCycler ${ }^{\circledR}$ FastStart DNA Master SYBR-Green I and $6.3 \mu \mathrm{l}$ of PCR grade $\mathrm{H}_{2} \mathrm{O}$. Simultaneously, $1 \mu \mathrm{l}$ of DNA from $143 \mathrm{~B}$ cells $(1 \mathrm{ng} / \mu \mathrm{l})$ and PCR grade $\mathrm{H}_{2} \mathrm{O}$ were included as positive and negative controls, respectively. The PCR conditions were set as: hot start at $95^{\circ} \mathrm{C}$ for $10 \mathrm{~min}$ followed by 40 cycles of $95^{\circ} \mathrm{C}$ for $20 \mathrm{sec}$, 
$62^{\circ} \mathrm{C}$ for $20 \mathrm{sec}$ and $72^{\circ} \mathrm{C}$ for $20 \mathrm{sec}$. Fluorescence intensity for $\mathrm{Ct}$ value detection was measured at the end of every extension phase at $79^{\circ} \mathrm{C}$. Using the equations of the established standard curves, the mtDNA copies and nDNA copies of sample DNA relative to those of $143 \mathrm{~B}$ cells $(1 \mathrm{ng} / \mu \mathrm{l})$ were determined. The mtDNA copy number (total mtDNA copies/total nDNA copies; i.e. relative mtDNA copies to $143 \mathrm{~B} /$ relative nDNA copies to 143B) of each clinical sample was determined after adjusting the mtDNA copy number of the 143B cells to 1.000. Each reaction was carried out in duplicate and the mean value was used for data presentation. To evaluate the change in mtDNA copy number between the BIDC and paired non-cancerous breast tissues, we defined mtDNA copy ratio as the mtDNA copy number of the BIDC divided by mtDNA copy number of the paired non-cancerous breast tissue.

Sequencing of the D310 region. The D310 region of mtDNA was amplified by PCR and then subjected to direct sequencing as previously described $(20,23,24)$. Each $50 \mu 1$ PCR reaction contained $25 \mu 1$ of RBC SensiZyme ${ }^{\circledR}$ Hotstart Taq Premix (RBC Bioscience, New Taipei City, Taiwan), $22 \mu 1$ of PCR-grade $\mathrm{H}_{2} \mathrm{O}, 1 \mu$ l of each primer (H76-1, 5'-CACGCGATA GCATTGCGA-3'; and L335, 5'-TAAGTGCTGTGGCCAGA AGC-3'), and $1 \mu \mathrm{l}$ of sample DNA (10 $\mathrm{ng} / \mu \mathrm{l})$. The PCR procedures included a hot start at $95^{\circ} \mathrm{C}$ for 10 min, 40 cycles of $95^{\circ} \mathrm{C}$ for $15 \mathrm{sec}, 58^{\circ} \mathrm{C}$ for $15 \mathrm{sec}$ and $72^{\circ} \mathrm{C}$ for $30 \mathrm{sec}$, and a final extension at $72^{\circ} \mathrm{C}$ for $7 \mathrm{~min}$. After confirmation by $3 \%$ agarose gel electrophoresis, the PCR products were subjected to direct sequencing (MB Mission Biotech, Taipei, Taiwan). The D310 sequence variations, including patterns of homoplasmy or heteroplasmy, number of detected D310 variants, and the predominant D310 variant were determined as previously described $(20,23,24)$. Compared to the D310 sequences of the paired non-cancerous breast tissue, any sequence alterations detected in the BIDC were defined as D310 mutations (20).

Immunohistochemical staining. The expression levels of ER, PR, HER-2/neu, p53 and Ki-67 were determined by immunohistochemical (IHC) staining, and these parameters are routinely determined in the pathological examinations in our hospital. Thin sections $(\sim 4-\mu \mathrm{m})$ from the formalin-fixed and paraffin-embedded tissues blocks were cut for IHC staining. Characteristics of the primary antibodies used for IHC and their criteria for positive/high expression are illustrated in Table I. Briefly, the sections were de-paraffinized with xylene (Merck KGaA) and then rehydrated with 100\% alcohol, 95\% alcohol solution and pure distilled running water in steps. After reacting with target retrieval solution (EnVision ${ }^{\mathrm{TM}}$ FLEX, pH 9.0, 50X, K8004; pH 6.0, 10X, S2369; both from Dako, Carpinteria, CA, USA) at $99^{\circ} \mathrm{C}$ for $20 \mathrm{~min}$, they were cooled at room temperature for $20 \mathrm{~min}$ and incubated in TBS buffer (EnVision $^{\text {TM }}$ FLEX Wash Buffer, 20X, K8007; Dako) for 5 min. Endogenous peroxidase was blocked with peroxidase-blocking reagent (DM821; Dako) for 5 min. After washing with TBS, the primary antibodies were applied at room temperature for $20 \mathrm{~min}$ (HER-2/neu, $30 \mathrm{~min}$ ). After washing with TBS, the sections were incubated with horseradish peroxidase (HRP; DM822; Dako) at room temperature for $20 \mathrm{~min}$, and the sections were again washed in TBS. The color was developed by $10 \mathrm{~min}$ of incubation with 3,3-diaminobenzidine tetrahydrochloride

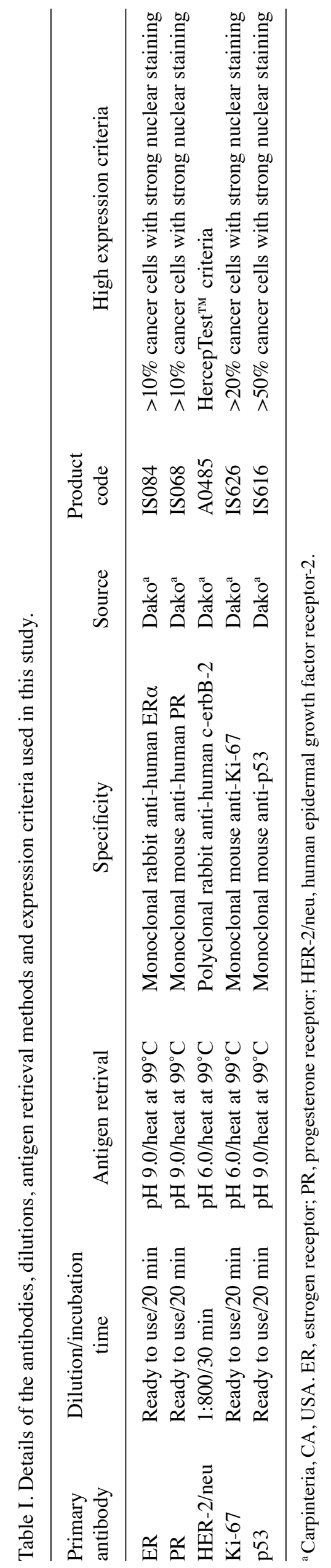


I. Homoplamic to homoplasmic alteration - without D310 mutation

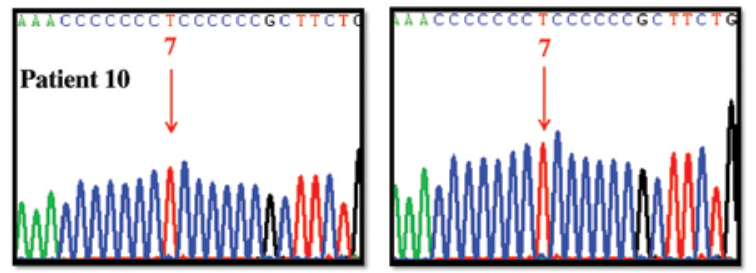

II. Heteroplasmic to heteroplasmic alteration - without D310 mutation

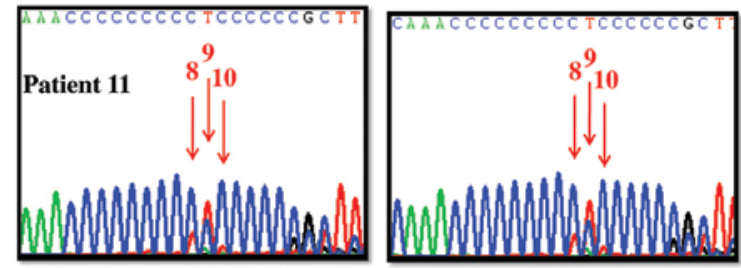

III. Homoplasmic to heteroplasmic - with D310 mutation

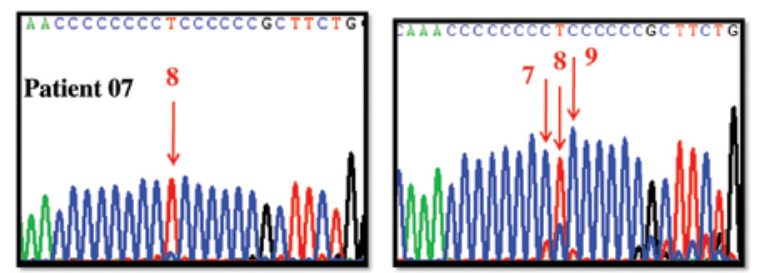

IV. Heteroplasmic to heteroplasmic - with D310 mutation

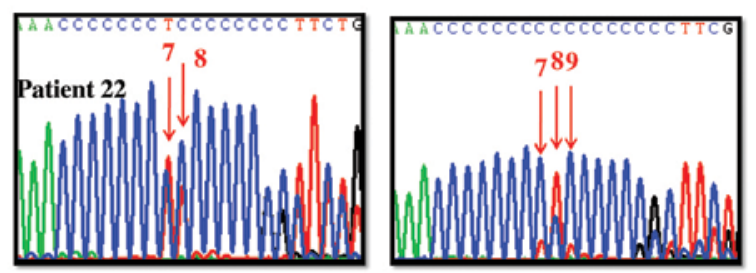

V. Heteroplasmic to homoplasmic - with D310 mutation

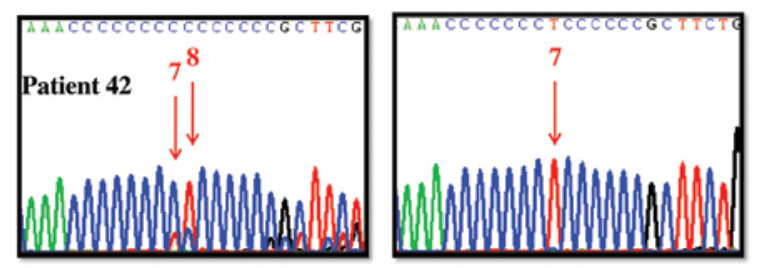

solution (DAB; + chromogen, DM827; diluted in substrate buffer, SM803; both from Dako). The sections were weakly counterstained with hematoxylin (Merck).

Statistical analyses. All the statistical analyses were performed using the Statistical Package for the Social Sciences (SPSS), version 15.0, software (SPSS, Inc., Chicago, IL, USA). The continuous variables were compared using the Student's t-test/Mann-Whitney U test between two groups or ANOVA/Kruskal-Wallis H test among three or more groups when appropriate. Categorical variables between groups were compared using the Chi-square/Fisher's exact tests or
Figure 1. Representative cases to demonstrate the mitochondrial DNA D310 sequence variations and their shifting between non-cancerous breast tissue (left) and paired breast IDC (right). T (thymidine) is shown in red, A (adenine) in green, $\mathrm{C}$ (cytidine) in blue and $\mathrm{G}$ (guanine) in black during sequencing. The Arabic number above the red arrow denotes the $\mathrm{C}$ number before the indicated $\mathrm{T}$ peak and the $\mathrm{T}$ peak height represents the relative quantity of the D310 variant. Type I, homoplasmic to homoplasmic (first row) without D310 mutation; patient 10 as an example. Her non-cancerous breast tissue harbors one type of $\mathrm{D} 310$ variant, the $\mathrm{C}_{7} \mathrm{TC}_{6}$ and is classified as homoplasmic D310 with $\mathrm{C}_{7} \mathrm{TC}_{6}$ as the major one. Her BIDC also harbors one type of D310 variant, the $\mathrm{C}_{7} \mathrm{TC}_{6}$, and is classified as homoplasmic $\mathrm{D} 310$ with $\mathrm{C}_{7} \mathrm{TC}_{6}$ as the major one. As a result, patient 10 was defined as type I homoplasmic to homoplasmic alteration without D310 mutation. Type II, heteroplasmic to heteroplasmic (second row) without D310 mutation; patient 11 as an example. Her non-cancerous breast tissue harbors 3 types of D310 variants, the $\mathrm{C}_{9} \mathrm{TC}_{6}$, $\mathrm{C}_{8} \mathrm{TC}_{6}$ and $\mathrm{C}_{10} \mathrm{TC}_{6}$ in order, and is classified as heteroplasmic D310 with $\mathrm{C}_{9} \mathrm{TC}_{6}$ as the major one. Her BIDC also harbors 3 types of D310 variants, the $\mathrm{C}_{9} \mathrm{TC}_{6}, \mathrm{C}_{8} \mathrm{TC}_{6}$ and $\mathrm{C}_{10} \mathrm{TC}_{6}$ in order, and is classified as heteroplasmic D310 with $\mathrm{C}_{9} \mathrm{TC}_{6}$ as the major one. No significant shifting of the D310 sequence variations was noted. As a result, patient 11 was defined as heteroplasmic to heteroplasmic alteration without D310 mutation. Type III, homoplasmic to heteroplasmic (third row) with D310 mutation; patient 07 as an example. Her non-cancerous breast tissue harbors one type of D310 variants, the $\mathrm{C}_{8} \mathrm{TC}_{6}$, and is classified as homoplasmic D310 with $\mathrm{C}_{8} \mathrm{TC}_{6}$ as the major one. Her BIDC harbors 3 types of $\mathrm{D} 310$ variants, the $\mathrm{C}_{8} \mathrm{TC}_{6}, \mathrm{C}_{7} \mathrm{TC}_{6}$ and $\mathrm{C}_{9} \mathrm{TC}_{6}$ in order, and is classified as heteroplasmic D310 with $\mathrm{C}_{8} \mathrm{TC}_{6}$ as the major one. Significant shifting of the D310 sequence variations was noted. As a result, patient 07 was defined as homoplasmic to heteroplasmic alteration with $\mathrm{D} 310$ mutation. Type IV, heteroplasmic to heteroplasmic (fourth row) with D310 mutation; patient 22 as an example. Her non-cancerous breast tissue harbors 2 types of D310 variants, the $\mathrm{C}_{7} \mathrm{TC}_{6}$ and $\mathrm{C}_{8} \mathrm{TC}_{6}$ in order, and is classified as heteroplasmic D310 with $\mathrm{C}_{7} \mathrm{TC}_{6}$ as the major one. Her BIDC harbors 3 types of D310 variants, the $\mathrm{C}_{8} \mathrm{TC}_{6}, \mathrm{C}_{7} \mathrm{TC}_{6}$ and $\mathrm{C}_{9} \mathrm{TC}_{6}$ in order, and is classified as heteroplasmic D310 with $\mathrm{C}_{8} \mathrm{TC}_{6}$ as the major one. Significant shifting of the D310 sequence variations were noted. As a result, patient 22 was defined as heteroplasmic to heteroplasmic alteration with D310 mutation. Type V, heteroplasmic to homoplasmic (fifth row) with D310 mutation; patient 42 as an example. Her non-cancerous breast tissue harbors 2 types of D310 variants, the $\mathrm{C}_{8} \mathrm{TC}_{6}$ and $\mathrm{C}_{7} \mathrm{TC}_{6}$ in order, and is classified as heteroplasmic D310 with $\mathrm{C}_{8} \mathrm{TC}_{6}$ as the major one. Her breast IDC harbors one type of $\mathrm{D} 310$ variant, the $\mathrm{C}_{7} \mathrm{TC}_{6}$, and is classified as homoplasmic D310 with $\mathrm{C}_{7} \mathrm{TC}_{6}$ as the major one. Significant shifting of the D310 sequence variations were noted. As a result, patient 42 was defined as heteroplasmic to homoplasmic alteration with D310 mutation.

Chi-square test for trend when appropriate. The difference between groups was considered to indicate a statistically significant result when the $\mathrm{p}$-value was $<0.05$.

\section{Results}

mtDNA D310 sequence variations and mtDNA copy numbers of examined tissues and their alterations. The results of the mtDNA D310 sequence variations and mtDNA copy numbers of the non-cancerous breast tissues and paired BIDCs and their alterations are listed in Table II and classified in Fig. 1. For non-cancerous breast tissues, the mean detected D310 


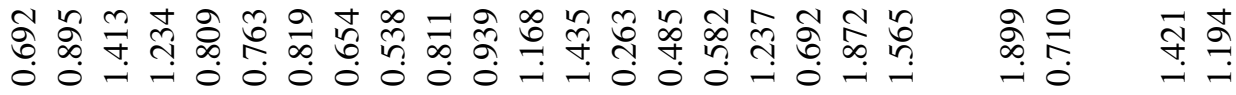

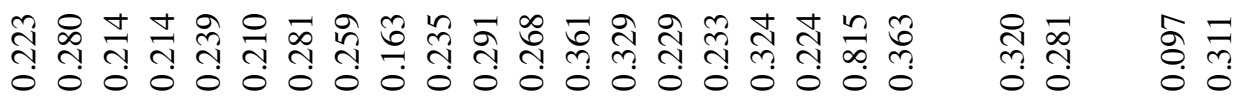

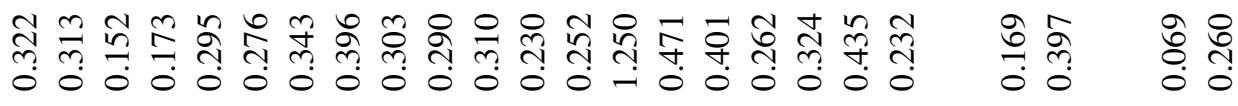

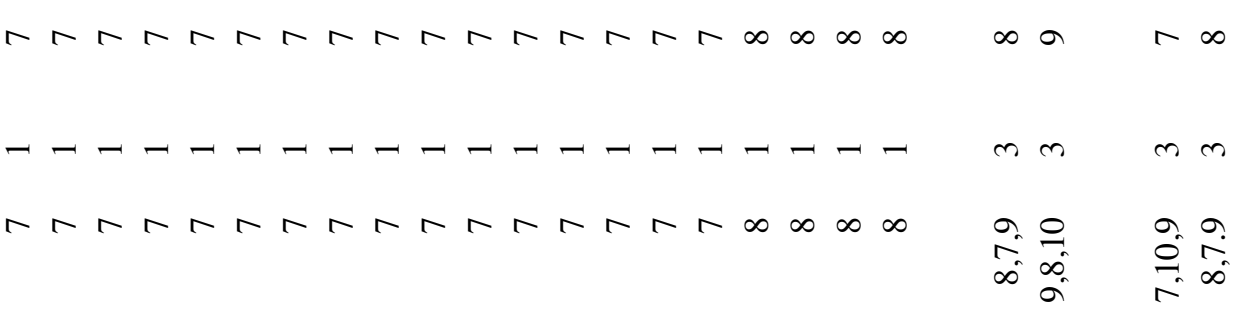

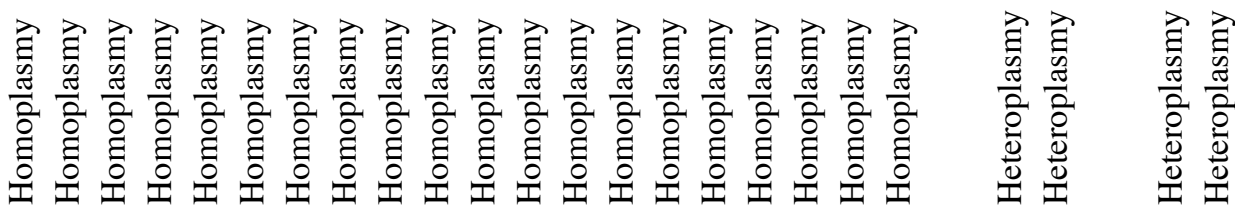

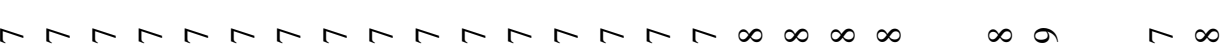

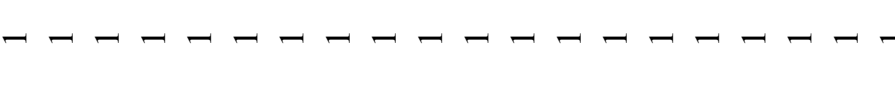

$\operatorname{chthththththththom~} \cos$

$\begin{array}{ll}2 & 0 \\ \infty & \infty \\ \infty & \infty\end{array}$

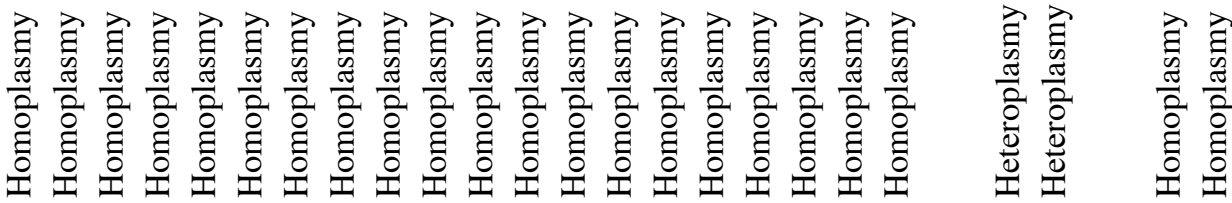

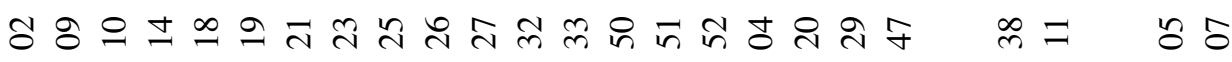

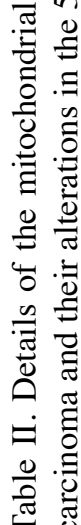




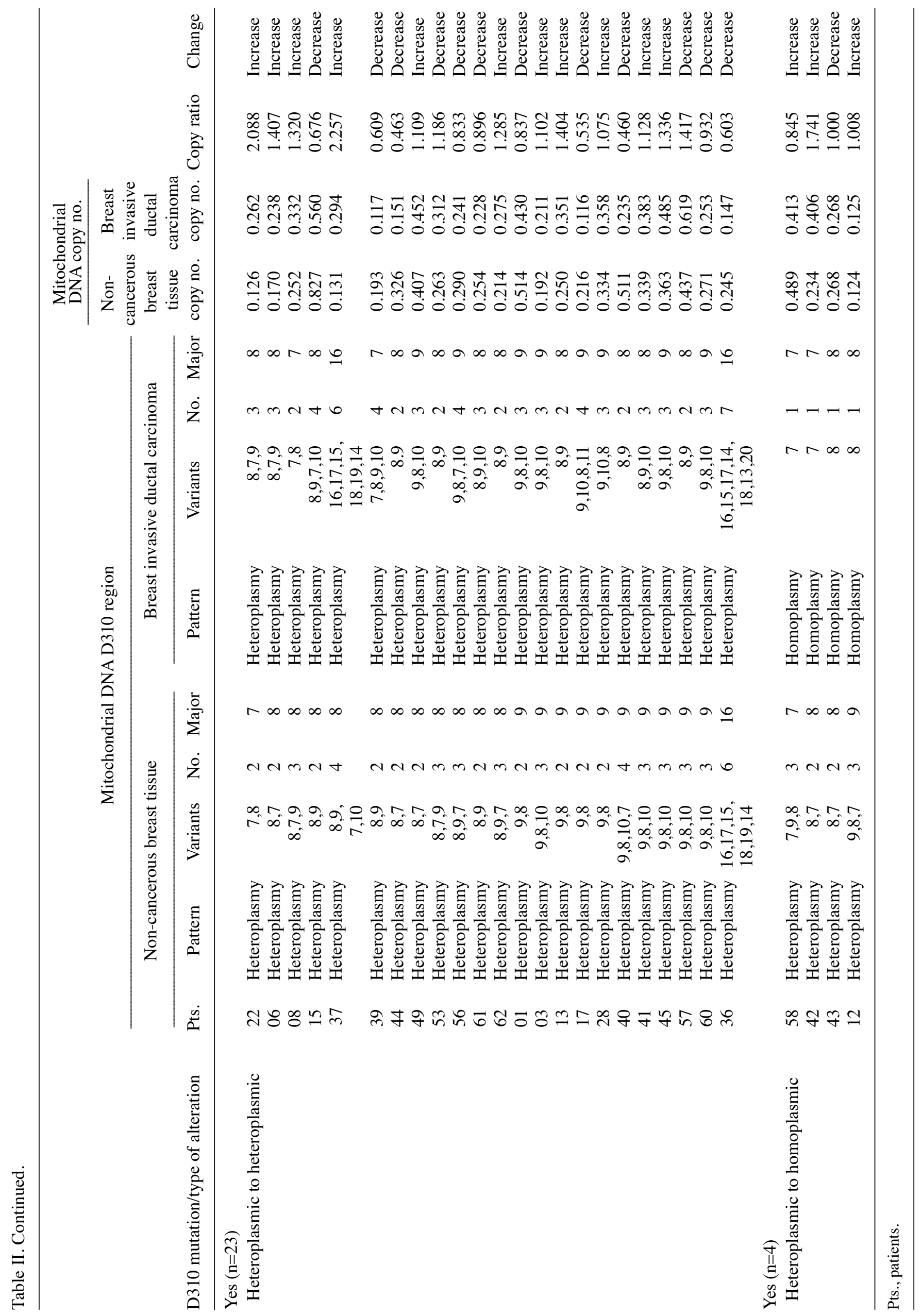


Table III. Distribution of mitochondrial DNA D310 and mitochondrial DNA copy number of the non-cancerous breast tissue and paired breast invasive ductal carcinoma in the 51 BIDC women.

\begin{tabular}{lcc}
\hline Mitochondrial DNA & $\begin{array}{c}\text { Non-cancerous } \\
\text { breast tissue }\end{array}$ & $\begin{array}{c}\text { Breast invasive } \\
\text { ductal carcinoma }\end{array}$ \\
\hline $\begin{array}{l}\text { D310 pattern (n, \%) } \\
\text { Homoplasmic }\end{array}$ & $22(43.1)$ & $24(47.1)$ \\
Heteroplasmic & $29(56.9)$ & $27(52.9)$ \\
No. of D310 variants & & \\
Mean \pm SD & $2.0 \pm 1.1$ & $2.1 \pm 1.4$ \\
(95\% CI of mean) & $(1.7-2.3)$ & $(1.8-2.6)$ \\
Copy no. & & $0.295 \pm 0.130$ \\
Mean \pm SD & $0.317 \pm 0.184$ & $(0.250-0.360)$ \\
(95\% CI of mean) & $(0.269-0.385)$ & \\
\hline
\end{tabular}

variants and mean mtDNA copy numbers were 2.0 and 0.317 , respectively, and 29 (56.9\%) harbored a heteroplasmic D310 pattern. For BIDCs, their mean detected D310 variants and mtDNA copy numbers were 2.1 and 0.295 , respectively, and 27 (52.9\%) harbored a heteroplasmic D310 pattern (Table III). When compared to the paired non-cancerous breast tissues, 29 (56.9\%) BIDCs harbored D310 mutations, and 24 (47.1\%) had an increased mtDNA copy number with mtDNA copy ratio $>1.000$ (Table IV).

Clinicopathological demographic data. The demographic data concerning the clinical, pathological and biochemical analyses of the 51 BIDC women are listed in Table IV. The mean age was 53.6 and the mean tumor diameter was $2.5 \mathrm{~cm}$. After pathological examinations, the mean total dissected axillary lymph nodes was 17.0 with a mean number of positive nodes of 1.8. Concerning the pathological T- and N-status and cancer stage, $24(47.1 \%), 21(41.2 \%)$ and $6(11.8 \%)$ belonged to T1, T2 and T3; $30(58.8 \%), 13(25.5), 6(11.8 \%)$ and $2(3.9 \%)$ to $\mathrm{N} 0, \mathrm{~N} 1, \mathrm{~N} 2$ and N3; and $17(33.3 \%), 26(51 . \%)$ and $8(15.7 \%)$ to stages I-III, respectively. For the histological grade, $4(7.8 \%)$ belonged to grade I, $39(76.5 \%)$ to II and $8(15.7 \%)$ to III, respectively.

Concerning the expression of therapeutic biomarkers, 37 (72.5\%), 33 (64.7\%) and 14 (27.5\%) were positive for ER, PR and HER-2/neu, respectively. For the biomarkers reflecting tumor aggressiveness and proliferation, 14 (27.5\%) were positive for p53 expression and $9(17.6 \%)$ had a high Ki-67 expression.

Factors affecting mtDNA copy ratio. The possible factors that affect mtDNA copy ratio are listed in Table V. Advanced T-status $(p=0.056)$, negative-ER expression $(p=0.005)$, negative-PR expression ( $\mathrm{p}=0.007)$, positive-p53 $(\mathrm{p}=0.050)$ and $\mathrm{Ki}-67$ with high expression $(\mathrm{p}=0.004)$ were related to a higher mtDNA copy ratio in the BIDCs, respectively.

Factors related to the mtDNA D310 mutation. As shown in Table VI, advanced T-status ( $\mathrm{p}=0.019)$ and negative-HER-2/neu
Table IV. Demographic data concerning clinical, pathological and mitochondrial DNA features of the 51 BIDC women.

Demographic data Data

Age (years) mean $\pm \mathrm{SD}$

$53.6 \pm 11.4(50.5-56.8)$

(95\% CI of mean)

Tumor side, n (\%)

Left

$30(58.8)$

Right

$21(41.2)$

Tumor location, n (\%)

Outer-upper

$28(54.9)$

Outer-lower

9 (17.6)

Inner-upper

$9(17.6)$

Inner-lower

3 (5.9)

Sub-areolar

$2(3.9)$

Surgical-pathological findings

mean \pm SD $(95 \%$ CI of mean)

Tumor diameter $(\mathrm{cm})$

Total dissected lymph nodes

Positive-dissected lymph nodes

T-status, n (\%)

$\mathrm{T} 1$

$24(47.1)$

$\mathrm{T} 2$

21(41.2)

T3

$6(11.8)$

N-status, n (\%)

N0

$30(58.8)$

N1

$13(25.5)$

$\mathrm{N} 2$

$6(11.8)$

N3

2 (3.9)

Cancer stage, n (\%)

I

$17(33.3)$

II

$26(51.0)$

III

8 (15.7)

Histological grade, n (\%)

I

4 (7.8)

II

$39(76.5)$

8 (15.7)

Estrogen receptor, n (\%)

Negative

$14(27.5)$

Positive

$37(72.5)$

Progesterone receptor

Negative

$18(35.3)$

Positive

33 (64.7)

HER-2/neu

Negative

$37(72.5)$

Positive

$14(27.5)$

p53

Negative

$37(72.5)$

14 (27.5)

Ki-67

Low

42 (82.4)

High 
Table IV. Continued.

\begin{tabular}{lc}
\hline Demographic data & Data \\
\hline Mitochondrial DNA alteration, n (\%) & \\
D310 mutation & $29(56.9)$ \\
Yes & $22(43.1)$ \\
No & $1.052 \pm 0.441$ \\
Mitochondrial DNA copy ratio & \\
mtDNA copy number, $\mathrm{n}(\%)$ & $24(47.1)$ \\
Increase (ratio $>1.000)$ & $27(52.9)$ \\
Decrease (ratio $\leq 1.000)$ & \\
\hline
\end{tabular}

expression $(\mathrm{p}=0.061)$ were associated with a higher rate of D310 mutations in the human BIDCs.

\section{Discussion}

Surgical-pathological T-, N- and M-status and cancer stage of AJCC remain as the gold standard to predict the prognosis of BIDC women. With the advance in cancer research, the oncogenic process and the proliferative aggressiveness of BIDCs were found to be correlated to positive-p53 (tumor suppressor) and high Ki-67 (cell proliferation) expression, respectively. Furthermore, due to the breakthrough of modern molecular biology in the evaluation of specific cellular receptors, hormone ablation or targeted therapy have been advocated for BIDC women harboring positive-ER/PR or positive-HER-2/neu expression to improve their outcomes, in addition to routine adjuvant chemotherapy $(15,18,25-29)$. In this retrospective study, we demonstrated that: i) advanced T-status, negative-ER, negative-PR, positive-p53 and high $\mathrm{Ki}-67$ expression are related to higher mtDNA copy ratios in BIDCs; and ii) advanced T-status and negative-HER-2/neu are related to higher rates of mtDNA D310 mutations in BIDCs. Since mitochondria are the cellular powerhouse for energy production, whether these mtDNA alterations in human BIDCs are related to a metabolic shift warrants further appraisal and discussion. Metabolic shift in human cancer was first described by Dr Warburg 7 decades ago (Warburg effect), and he contended that human cancer tissues exhibited increased glycolysis yet decreased mitochondrial respiration to generate ATP (30-32). It also became the basic theory of positron emission tomography (PET) scan in cancer evaluation.

The changes in mtDNA copy numbers have been analyzed in several human type of cancers. Compared to the paired non-cancerous counterparts, a decrease in mtDNA copy number was reported in lung cancer (33), hepatocellular carcinoma (34) and gastric cancer (35). In lung cancer tissues after neoadjuvant chemotherapy, a progressive decrease in mtDNA copy number was correlated with disease progression (22). These decreases were thought to be decreases in mitochondrial function. On the contrary, an increase in mtDNA copy number was noted in the carcinogenesis of head and neck cancers (36), and the progression of esophageal squamous cell carcinomas (20), particularly in patients who smoked cigarettes. These increases were regarded as a compensation
Table V. Possible factors affecting mitochondrial DNA copy number ratio.

\begin{tabular}{|c|c|c|}
\hline Factors $(\mathrm{n}, \%)$ & $\begin{array}{l}\text { Mitochondrial DNA } \\
\text { copy no. ratio }\end{array}$ & P-value \\
\hline Age (years) & & 0.832 \\
\hline$\leq 50(\mathrm{n}=24,47.1)$ & $1.066 \pm 0.502$ & \\
\hline$>50(n=27,52.9)$ & $1.039 \pm 0.388$ & \\
\hline \multicolumn{3}{|l|}{ Pathological findings } \\
\hline T-status & & 0.056 \\
\hline $\mathrm{T} 1(\mathrm{n}=24,47.1)$ & $1.144 \pm 0.460$ & \\
\hline $\mathrm{T} 2(\mathrm{n}=21,41.2)$ & $0.878 \pm 0.341$ & \\
\hline T3 $(n=6,11.8)$ & $1.293 \pm 0.520$ & \\
\hline $\mathrm{N}$-status & & 0.131 \\
\hline N0 $(n=30,58.8)$ & $0.969 \pm 0.399$ & \\
\hline $\mathrm{N} 1(\mathrm{n}=13,25.5)$ & $1.218 \pm 0.470$ & \\
\hline $\mathrm{N} 2(\mathrm{n}=6,11.8)$ & $0.912 \pm 0.369$ & \\
\hline N3 $(n=2,3.9)$ & $1.637 \pm 0.637$ & \\
\hline Cancer stage & & 0.975 \\
\hline $\mathrm{I}(\mathrm{n}=17,33.3)$ & $1.053 \pm 0.412$ & \\
\hline II $(n=26,51.0)$ & $1.038 \pm 0.452$ & \\
\hline III $(n=8,15.7)$ & $1.093 \pm 0.518$ & \\
\hline Histological grade & & 0.215 \\
\hline $\mathrm{I}(\mathrm{n}=4,7.8)$ & $0.834 \pm 0.488$ & \\
\hline II $(n=39,76.5)$ & $1.042 \pm 0.465$ & \\
\hline III $(n=8,15.7)$ & $1.206 \pm 0.245$ & \\
\hline Estrogen receptor & & 0.005 \\
\hline Negative $(n=14,27.5)$ & $1.291 \pm 0.357$ & \\
\hline Positive $(\mathrm{n}=37,72.5)$ & $0.961 \pm 0.440$ & \\
\hline Progesterone receptor & & 0.007 \\
\hline Negative $(\mathrm{n}=18,35.3)$ & $1.233 \pm 0.372$ & \\
\hline Positive $(n=33,64.7)$ & $0.953 \pm 0.449$ & \\
\hline HER-2/neu & & 0.301 \\
\hline Negative $(n=37,72.5)$ & $1.012 \pm 0.433$ & \\
\hline Positive $(n=14,27.5)$ & $1.158 \pm 0.459$ & \\
\hline p53 & & 0.050 \\
\hline Negative $(n=37,72.5)$ & $0.983 \pm 0.426$ & \\
\hline Positive $(n=14,27.5)$ & $1.233 \pm 0.444$ & \\
\hline $\mathrm{Ki}-67$ & & 0.004 \\
\hline Low $(n=42,82.4)$ & $0.977 \pm 0.420$ & \\
\hline High $(n=9,17.6)$ & $1.399 \pm 0.382$ & \\
\hline
\end{tabular}

process to overcome the oxidative damages from cigarette smoking and to maintain proper mitochondrial function (19). Concerning BIDCs, a decrease in mtDNA copy number was reported in some research articles (37-39). Nevertheless, we demonstrated a significantly higher mtDNA copy ratio in BIDCs that harbored negative-ER, negative-PR, positive-p53 or high Ki-67 expression. Thus, we focused on the role of ER, PR, p53 and Ki-67 and their relationships to mtDNA in BIDCs. 
Table VI. Possible factors related to mitochondrial DNA D310 mutation.

\begin{tabular}{|c|c|c|c|}
\hline \multirow[b]{2}{*}{ Factors (n, \%) } & \multicolumn{2}{|c|}{$\begin{array}{l}\text { Mitochondrial DNA } \\
\text { D310 mutation }\end{array}$} & \multirow[b]{2}{*}{ P-value } \\
\hline & $\begin{array}{c}\text { No } \\
\mathrm{n}(\%)\end{array}$ & $\begin{array}{l}\text { Yes } \\
\mathrm{n}(\%)\end{array}$ & \\
\hline Total & $22(100)$ & $29(100)$ & \\
\hline $\begin{array}{l}\text { Age (years) } \\
\leq 50(\mathrm{n}=24,100.0) \\
>50(\mathrm{n}=27,100.0)\end{array}$ & $\begin{array}{l}11(45.8) \\
11(40.7)\end{array}$ & $\begin{array}{l}13(54.2) \\
16(59.3)\end{array}$ & 0.714 \\
\hline \multicolumn{4}{|l|}{ Pathological findings } \\
\hline $\begin{array}{l}\text { T-status } \\
\text { T1 }(n=24,100.0) \\
\text { T2 }(n=21,100.0) \\
\text { T3 }(n=6,100.0)\end{array}$ & $\begin{array}{c}9(37.5) \\
13(61.9) \\
0(0.0)\end{array}$ & $\begin{array}{r}15(62.5) \\
8(38.1) \\
6(100.0)\end{array}$ & 0.019 \\
\hline $\begin{array}{l}\text { N-status } \\
\text { N0 }(n=30,100.0) \\
\text { N1 }(n=13,100.0) \\
\text { N2 }(n=6,100.0) \\
\text { N3 }(n=2,100.0)\end{array}$ & $\begin{array}{c}14(46.7) \\
5(38.5) \\
3(50.0) \\
0(0.0)\end{array}$ & $\begin{array}{r}16(53.3) \\
8(61.5) \\
3(50.0) \\
2(100.0)\end{array}$ & 0.593 \\
\hline $\begin{array}{l}\text { Cancer stage } \\
\text { I }(\mathrm{n}=17,100.0) \\
\text { II }(\mathrm{n}=26,100.0) \\
\text { III }(\mathrm{n}=8,100.0)\end{array}$ & $\begin{array}{r}6(35.3) \\
13(50.0) \\
3(37.5)\end{array}$ & $\begin{array}{r}11(64.7) \\
13(50.0) \\
5(62.5)\end{array}$ & 0.598 \\
\hline $\begin{array}{l}\text { Histological grade } \\
\text { I }(\mathrm{n}=4,100.0) \\
\text { II }(\mathrm{n}=39,100.0) \\
\text { III }(\mathrm{n}=8,100.0)\end{array}$ & $\begin{array}{r}1(25.0) \\
17(43.6) \\
4(50.0)\end{array}$ & $\begin{array}{r}3(75.0) \\
22(56.4) \\
4(50.0)\end{array}$ & 0.707 \\
\hline $\begin{array}{l}\text { Estrogen receptor } \\
\text { Negative }(n=14,100.0) \\
\text { Positive }(n=37,100.0)\end{array}$ & $\begin{array}{r}6(42.9) \\
16(43.2)\end{array}$ & $\begin{array}{r}8(57.1) \\
21(56.8)\end{array}$ & \\
\hline $\begin{array}{l}\text { Progesterone receptor } \\
\text { Negative }(n=18,100.0) \\
\text { Positive }(n=33,100.0)\end{array}$ & $\begin{array}{r}8(44.4) \\
14(42.4)\end{array}$ & $\begin{array}{l}10(55.6) \\
19(57.6)\end{array}$ & 0.889 \\
\hline $\begin{array}{l}\text { HER-2 /neu } \\
\text { Negative }(n=37,100.0) \\
\text { Positive }(n=14,100.0)\end{array}$ & $\begin{array}{r}13(35.1) \\
9(64.3)\end{array}$ & $\begin{array}{r}24(64.9) \\
5(35.7)\end{array}$ & 0.061 \\
\hline $\begin{array}{l}\text { P53 } \\
\text { Negative }(n=37,100.0) \\
\text { Positive }(n=14,100.0)\end{array}$ & $\begin{array}{r}14(37.8) \\
8(57.1)\end{array}$ & $\begin{array}{r}23(62.2) \\
6(42.9)\end{array}$ & 0.214 \\
\hline $\begin{array}{l}\text { Ki-67 } \\
\text { Low }(n=42,100.0) \\
\text { High }(n=9,100.0)\end{array}$ & $\begin{array}{r}20(47.6) \\
2(22.2)\end{array}$ & $\begin{array}{r}22(52.4) \\
7(77.8)\end{array}$ & 0.163 \\
\hline
\end{tabular}

ER and PR both belong to the nuclear receptors, which can interact with the hormone response element (HRE) in nDNA, after the binding of estrogen or progesterone. With regards to ER, it not only can activate estrogen HRE in nDNA to control cell proliferation and apoptosis in several tissues yet also can be imported into the mitochondria to interact with the mtDNA to increase the expression of mtDNA-encoded peptides, and mitochondrial biogenesis due to mtDNA also harbors sequences similar to the HRE of nDNA (HRE-like motif) (40). Furthermore, an in vitro study denoted that the interactions among the estrogen, ER and HRE-like motif in mtDNA were crucial to maintain mitochondrial function, inhibit cell apoptosis, and overcome oxidative damage in breast cancer cell line, MCF-7 (41). Concerning PR, similar effects were also observed in benign breast epithelial cells (42). As a result, we proposed that an increase in mtDNA copy numbers in BIDCs that harbor negative-ER or negative-PR expression are thought to be a compensation process to enhance the interaction between ER/PR and HRE motifs on mtDNA to maintain mitochondrial function.

Concerning the associations among p53, mitochondria and mtDNA, pilot studies have shown that functional p53 may participate in the regulation of cellular mitochondrial biogenesis and respiration (43-45), maintenance of mtDNA integrity (46), maintaining mtDNA copy number abundance (46) and the homeostasis of reactive oxygen species (47). In a normal cell, p53 is inactivated by its negative regulator, mdm2, as a result, the protein p53 is usually not detectable (48). Under stress or pathological situations, various pathways lead to the dissociation of the p53 and mdm 2 complex, which leads to an activated, accumulated and detectable p53. The activated p53 induces cell cycle arrest to allow either repair and survival of the cell or apoptosis to discard the damaged cells. Although the primary antibody that we used in the present study cannot distinguish wild-type or mutant p53, the positively detected p53 did suggest an elevated stress in BIDCs. It is postulated that the elevated mtDNA copy ratio in BIDCs may indicate an enhanced interaction between p53 and mtDNA toward a possible metabolic shift or survival benefit.

High protein $\mathrm{Ki}-67$ expression denotes a high proliferative status (49). Ki-67 is detectable during all active phases of the cell cycle $\left(G_{1}, S, G_{2}\right.$ and mitosis) except the resting status $\left(\mathrm{G}_{0}\right)$. High Ki-67 expression in BIDCs means a highly proliferation situation of the cancer cells and is associated with a poor outcome $(15,16)$. It is reasonable to hypothesize that the elevated mtDNA copy ratio in BIDCs with high Ki-67 expression is regarded as increased energy expenditure for the rapid growth of cancer cells.

In addition to quantitative change of mtDNA copy number, several studies also evaluated the qualitative mtDNA D310 mutations in human types of cancers, including prostate $(50,51)$, head and neck $(52)$ and lung cancer $(53,54)$, and esophageal squamous cell carcinoma (20), and some showed clinical significance. In breast cancer, a D-loop mutation, including D310 mutation, was identified as a poor prognostic factor (39). Intriguingly, our results showed that negative-HER-2/neu expression was related to a higher rate of D310 mutation in BIDCs. Due to the fact that the mtDNA D310 is located near the binding side of mitochondrial transcriptional factor to control mitochondrial biogenesis (55), whether negative-HER-2/neu expression and D310 mutation are related to the functional alterations in BIDC mitochondria deserve further evaluation. Although the detailed interaction between HER-2/neu and mtDNA remains speculative, a recent novel study revealed that HER-2/neu can translocate into mitochondria to negatively 
regulate mitochondrial respiratory functions (56). Thus, it is assumed that an altered mitochondrial function may exist in BIDCs with negative HER-2/neu expression and mtDNA D310 mutation.

In addition to the above mentioned biomarkers of ER, PR, HER-2/neu, p53 and Ki-67, TNM status and cancer stages of AJCC remain the gold standard criteria to predict the prognosis of BIDC women. In our preliminary result, advanced T status was associated with a higher incidence of D310 mutation and an elevated mtDNA copy ratio. It is reasonable to assume that the increase in mtDNA copy number compensated for the mtDNA with D310 mutations when the BIDCs underwent progression, which was proposed in head and neck cancer and esophageal cancer $(19,20,36)$. To verify whether these increases in mtDNA copy number and mtDNA D310 mutations confer enhanced aggressiveness to BIDCs, further in vitro study is warrant.

Based on our preliminary results, we conclude that elevated mtDNA copy ratios and D310 mutations, suggesting an altered mitochondrial function, may be relevant biomarkers correlated with pathological T status and ER, PR, HER-2/neu, p53 and Ki-67 expression in BIDCs.

\section{Acknowledgements}

We would like to express our sincere appreciations to Hsin-Mei Kao for her excellent technique in the preparations of patholocial sections. This study was supported by grants from the Department of Health (DOH), Executive Yuan, Taiwan (nos. Taipei-100-03 and Taipei-101-02) to DOH Affiliated Taipei Hospital (DOH was named as the Ministry of Health and Welfare as of July 23, 2013).

\section{References}

1. Lee HC and Wei YH: Mitochondrial role in life and death of the cell. J Biomed Sci 7: 2-15, 2000.

2. Chan DC: Mitochondria: Dynamic organelles in disease, aging, and development. Cell 125: 1241-1252, 2006.

3. Lee HC and Wei YH: Mitochondrial biogenesis and mitochondrial DNA maintenance of mammalian cells under oxidative stress. Int J Biochem Cell Biol 37: 822-834, 2005.

4. Lightowlers RN, Chinnery PF, Turnbull DM and Howell N: Mammalian mitochondrial genetics: Heredity, heteroplasmy and disease. Trends Genet 13: 450-455, 1997.

5. Khrapko K, Coller HA, André PC, Li XC, Hanekamp JS and Thilly WG: Mitochondrial mutational spectra in human cells and tissues. Proc Natl Acad Sci USA 94: 13798-13803, 1997.

6. Yakes FM and Van Houten B: Mitochondrial DNA damage is more extensive and persists longer than nuclear DNA damage in human cells following oxidative stress. Proc Natl Acad Sci USA 94: 514-519, 1997.

7. Croteau DL, Stierum RH and Bohr VA: Mitochondrial DNA repair pathways. Mutat Res 434: 137-148, 1999.

8. Chinnery PF, Thorburn DR, Samuels DC, White SL, Dahl HM, Turnbull DM, Lightowlers RN and Howell N: The inheritance of mitochondrial DNA heteroplasmy: Random drift, selection or both? Trends Genet 16: 500-505, 2000.

9. Andrews RM, Kubacka I, Chinnery PF, Lightowlers RN, Turnbull DM and Howell N: Reanalysis and revision of the Cambridge reference sequence for human mitochondrial DNA. Nat Genet 23: 147, 1999.

10. Asin-Cayuela J and Gustafsson CM: Mitochondrial transcription and its regulation in mammalian cells. Trends Biochem Sci 32: 111-117, 2007.

11. Moraes CT: What regulates mitochondrial DNA copy number in animal cells? Trends Genet 17: 199-205, 2001.

12. Mambo E, Gao X, Cohen Y, Guo Z, Talalay P and Sidransky D: Electrophile and oxidant damage of mitochondrial DNA leading to rapid evolution of homoplasmic mutations. Proc Natl Acad Sci USA 100: 1838-1843, 2003.
13. Jemal A, Siegel R, Xu J and Ward E: Cancer statistics, 2010. CA Cancer J Clin 60: 277-300, 2010.

14. Berry DA, Inoue L, Shen Y, Venier J, Cohen D, Bondy M, Theriault R and Munsell MF: Modeling the impact of treatment and screening on U.S. breast cancer mortality: A Bayesian approach. J Natl Cancer Inst Monogr 2006: 30-36, 2006.

15. Mylonas I, Makovitzky J, Jeschke U, Briese V, Friese K and Gerber B: Expression of Her2/neu, steroid receptors (ER and PR), Ki67 and p53 in invasive mammary ductal carcinoma associated with ductal carcinoma In Situ (DCIS) Versus invasive breast cancer alone. Anticancer Res 25: 1719-1723, 2005.

16. Cheang MC, Chia SK, Voduc D, Gao D, Leung S, Snider J, Watson M, Davies S, Bernard PS, Parker JS, et al: Ki67 index, HER2 status, and prognosis of patients with luminal B breast cancer. J Natl Cancer Inst 101: 736-750, 2009.

17. Hugh J, Hanson J, Cheang MC, Nielsen TO, Perou CM, Dumontet C, Reed J, Krajewska M, Treilleux I, Rupin M, et al: Breast cancer subtypes and response to docetaxel in node-positive breast cancer: Use of an immunohistochemical definition in the BCIRG 001 trial. J Clin Oncol 27: 1168-1176, 2009.

18. Dawood S: Triple-negative breast cancer: Epidemiology and management options. Drugs 70: 2247-2258, 2010.

19. Lin CS, Wang LS, Chou TY, Hsu WH, Lin HC, Lee SY, Lee MH, Chang SC and Wei YH: Cigarette smoking and hOGG1 Ser326Cys polymorphism are associated with 8-OHdG accumulation on mitochondrial DNA in thoracic esophageal squamous cell carcinoma. Ann Surg Oncol 20 (Suppl 3): S379-S388, 2013.

20. Lin CS, Chang SC, Wang LS, Chou TY, Hsu WH, Wu YC and Wei YH: The role of mitochondrial DNA alterations in esophageal squamous cell carcinomas. J Thorac Cardiovasc Surg 139: 189.e4-197.e4, 2010.

21. Bai RK, Perng CL, Hsu CH and Wong LJ: Quantitative PCR analysis of mitochondrial DNA content in patients with mitochondrial disease. Ann NY Acad Sci 1011: 304-309, 2004.

22. Lin CS, Wang LS, Tsai CM and Wei YH: Low copy number and low oxidative damage of mitochondrial DNA are associated with tumor progression in lung cancer tissues after neoadjuvant chemotherapy. Interact Cardiovasc Thorac Surg 7: 954-958, 2008.

23. Lee HT, Lin CS, Chen WS, Liao HT, Tsai CY and Wei YH: Leukocyte mitochondrial DNA alteration in systemic lupus erythematosus and its relevance to the susceptibility to lupus nephritis. Int J Mol Sci 13: 8853-8868, 2012.

24. Wang PN, Lee HC, Wang CH, Ping YH, Liu TY, Chi CW, Lin KN and Liu HC: Heteroplasmy of mitochondrial D310 mononucleotide repeat region in the blood of patients with Alzheimer's disease. J Alzheimers Dis 18: 345-353, 2009.

25. Nishimura R, Osako T, Okumura Y, Tashima R, Toyozumi Y and Arima N: Changes in the ER, PgR, HER2, p53 and Ki-67 biological markers between primary and recurrent breast cancer: Discordance rates and prognosis. World J Surg Oncol 9: 131, 2011.

26. Taneja P, Maglic D, Kai F, Zhu S, Kendig RD, Fry EA and Inoue K: Classical and novel prognostic markers for breast cancer and their clinical significance. Clin Med Insights Oncol 4: 15-34, 2010.

27. Carter CL, Allen C and Henson DE: Relation of tumor size, lymph node status, and survival in 24,740 breast cancer cases. Cancer 63: 181-187, 1989.

28. Cianfrocca M and Goldstein LJ: Prognostic and predictive factors in early-stage breast cancer. Oncologist 9: 606-616, 2004.

29. Cianfrocca M and Gradishar W: New molecular classifications of breast cancer. CA Cancer J Clin 59: 303-313, 2009.

30. Warburg O: On respiratory impairment in cancer cells. Science 124: 269-270, 1956.

31. Warburg O: On the origin of cancer cells. Science 123: 309-314, 1956.

32. Warburg O: Origin of cancer cells. Oncologia 9: 75-83, 1956 (In German).

33. Lee HC, Yin PH, Lin JC, Wu CC, Chen CY, Wu CW, Chi CW, Tam TN and Wei YH: Mitochondrial genome instability and mtDNA depletion in human cancers. Ann NY Acad Sci 1042: 109-122, 2005.

34. Yin PH, Lee HC, Chau GY, Wu YT, Li SH, Lui WY, Wei YH, Liu TY and Chi CW: Alteration of the copy number and deletion of mitochondrial DNA in human hepatocellular carcinoma. Br J Cancer 90: 2390-2396, 2004.

35. Wu CW, Yin PH, Hung WY, Li AF, Li SH, Chi CW, Wei YH and Lee HC: Mitochondrial DNA mutations and mitochondrial DNA depletion in gastric cancer. Genes Chromosomes Cancer 44: 19-28, 2005. 
36. Kim MM, Clinger JD, Masayesva BG, Ha PK, Zahurak ML Westra WH and Califano JA: Mitochondrial DNA quantity increases with histopathologic grade in premalignant and malignant head and neck lesions. Clin Cancer Res 10: 8512-8515, 2004.

37. Fan AX, Radpour R, Haghighi MM, Kohler C, Xia P, Hahn S, Holzgreve W and Zhong XY: Mitochondrial DNA content in paired normal and cancerous breast tissue samples from patients with breast cancer. J Cancer Res Clin Oncol 135: 983-989, 2009.

38. Bai RK, Chang J, Yeh KT, Lou MA, Lu JF, Tan DJ, Liu H and Wong LJ: Mitochondrial DNA content varies with pathological characteristics of breast cancer. J Oncol 2011: 496189, 2011.

39. Tseng LM, Yin PH, Chi CW, Hsu CY, Wu CW, Lee LM, Wei YH and Lee HC: Mitochondrial DNA mutations and mitochondrial DNA depletion in breast cancer. Genes Chromosomes Cancer 45: 629-638, 2006

40. Chen JQ, Yager JD and Russo J: Regulation of mitochondrial respiratory chain structure and function by estrogens/estrogen receptors and potential physiological/pathophysiological implications. Biochim Biophys Acta 1746: 1-17, 2005.

41. Pedram A, Razandi M, Wallace DC and Levin ER: Functional estrogen receptors in the mitochondria of breast cancer cells. Mol Biol Cell 17: 2125-2137, 2006.

42. Behera MA, Dai Q, Garde R, Saner C, Jungheim E and Price TM: Progesterone stimulates mitochondrial activity with subsequent inhibition of apoptosis in MCF-10A benign breast epithelial cells . Am J Physiol Endocrinol Metab 297: E1089-E1096, 2009.

43. Bensaad K and Vousden KH: p53: New roles in metabolism. Trends Cell Biol 17: 286-291, 2007.

44. Matoba S, Kang JG, Patino WD, Wragg A, Boehm M, Gavrilova O, Hurley PJ, Bunz F and Hwang PM: p53 regulates mitochondrial respiration. Science 312: 1650-1653, 2006.

45. Saleem A, Adhihetty PJ and Hood DA: Role of p53 in mitochondrial biogenesis and apoptosis in skeletal muscle. Physiol Genomics 37: 58-66, 2009.

46. Kulawiec M, Ayyasamy V and Singh KK: p53 regulates mtDNA copy number and mitocheckpoint pathway. J Carcinog 8: 8, 2009.
47. Lebedeva MA, Eaton JS and Shadel GS: Loss of p53 causes mitochondrial DNA depletion and altered mitochondrial reactive oxygen species homeostasis. Biochim Biophys Acta 1787: 328-334, 2009.

48. Moll UM and Petrenko O: The MDM2-p53 interaction. Mol Cancer Res 1: 1001-1008, 2003.

49. Scholzen T and Gerdes J: The Ki-67 protein: From the known and the unknown. J Cell Physiol 182: 311-322, 2000.

50. Chen JZ, Gokden N, Greene GF, Mukunyadzi P and Kadlubar FF: Extensive somatic mitochondrial mutations in primary prostate cancer using laser capture microdissection. Cancer Res 62: 6470-6474, 2002.

51. Chen JZ and Kadlubar FF: Mitochondrial mutagenesis and oxidative stress in human prostate cancer. J Environ Sci Health C Environ Carcinog Ecotoxicol Rev 22: 1-12, 2004.

52. Lièvre A, Blons H, Houllier AM, Laccourreye O, Brasnu D, Beaune P and Laurent-Puig P: Clinicopathological significance of mitochondrial D-Loop mutations in head and neck carcinoma. Br J Cancer 94: 692-697, 2006

53. Suzuki M, Toyooka S, Miyajima K, Iizasa T, Fujisawa T, Bekele NB and Gazdar AF: Alterations in the mitochondrial displacement loop in lung cancers. Clin Cancer Res 9: 5636-5641, 2003.

54. Onishi M, Saito M, Sokuza Y, Mori C, Nishikawa T, Shimizu K, Sugata $\mathrm{E}$ and Tsujiuchi T: Numerical changes in the mitochondrial DNA displacement loop in lung lesions induced by $N$-nitrosobis(2-hydroxypropyl)amine in rats. Mutat Res 638: 133-138, 2008

55. Fisher RP, Topper JN and Clayton DA: Promoter selection in human mitochondria involves binding of a transcription factor to orientation-independent upstream regulatory elements. Cell 50: 247-258, 1987.

56. Ding Y, Liu Z, Desai S, Zhao Y, Liu H, Pannell LK, Yi H, Wright ER, Owen LB, Dean-Colomb W, et al: Receptor tyrosine kinase ErbB2 translocates into mitochondria and regulates cellular metabolism. Nat Commun 3: 1271, 2012. 